\title{
IRF (INITIATION-RESPONSE-FEEDBACK) ON CLASSROOM INTERACTION FOR COMPUTER STUDENTS IN SMK 1 YAPIM MEDAN
}

\author{
"Shilvia Pratiwi \\ "Dra.Meisuri, M.A \\ *Nora Ronita Dewi S.Pd., S.S., M.Hum
}

\begin{abstract}
This study was about IRF (Initiation-Response-Feedback) On Classroom Interaction For Computer Students in SMK 1 Yapim Medan. The aim of this study were to state clearly the objectives of the study in relation of the problems posed. The objective was to describe how the pattern of IRF in the classroom interaction for computer students. This research used qualitative research. The data were collected in three ways by observing by video recording, interviewing and questionnaire. The data was analyzed based on Sinclair and Coulthard theory (1975). The result of this study were the following (1) The language used by the teacher and the students in the classroom interaction was not balance. Both teacher and students used bahasa for $70 \%$ and the rest $30 \%$ for English. (2) There was the lowest pattern responded by student. It had $20 \%$ responses given to the students because the students made many mistakes in pronouncing some words when they read the text. The teacher feedback was the dominat pattern in the classroom interaction rather than initiation. It is suggested to English teacher especially for English teacher who is teaching computer students to improve students English by by having practice and supporting them to be brave to speak English.
\end{abstract}

Keywords: IRF (Initiation-Response-Feedback), Classroom Interaction, Computer Students

\footnotetext{
*Graduate Status

*** Lecturer Status
} 


\section{INTRODUCTION}

\section{Background of the Study}

Classroom interaction is necessary and useful as an educational strategy to enhance learning. The concept of classroom interaction plays a significant role in the process of second language learning. Classroom interaction is significant in the teaching and learning process because it determines the success of the teaching and learning process and improves students' language ability and achievement.

Classroom interaction can not be seperated from the teacher and students. Because teacher and students are the factors that establish classroom interaction. Both of them must be in balance. Too much teacher talk will make the students passive; they cannot improve their English. It has the certain pattern It has a certain pattern one of them is IRF pattern. This pattern stands for initiation-response-feedback, is a pattern of discussion between the teacher and learners. The teacher initiates, the learner responds, the teacher gives feedback, commonly known as IRF. This three part structure was first put forward by Sinclair \& Coulthard, 1975 and is known as the IRF exchange structure.

In Indonesia, English is as Foreign Language and taught from elementary to high school, the term of learning English, especially for Senior high School student based on The Teacher Training Material for Implementation of the 2013 Curriculum in year 2015; English Subject is, 
"The purpose of learning English language in high schools is to develop the potential of students to have communicative competencies the text, transactional and functional discourses, by using various spoken and written English texts coherently using accurate and acceptable linguistic elements, and various factual and procedural knowledge, and instill the noble values of the nation's character, in the context of life in the home, school and community environment" (Rohim, 2015).

Based on the researcher's observation to 38 Computer students of SMK 1 Yapim Medan, it was found that the common interaction occured in the classroom that the students would participated to talk if the lecturer initiated, encouraged and asks to the students to talk. The teacher opens the interaction by asking questions. The teacher was dominant in talking to the students. It was found that the students has problems in speaking. They often became reluctant to participate in a classroom interaction. For example, there are several students who are not able to express their idea in English both in written and oral form. Secondly, it seemed that the students did not have substantial amount of vocabulary mastery and thirdly the students often gave few respond when the teacher ask the question in the classroom. These problems caused by the quality of interaction between the teacher and the students, and the students and the teacher.

By referring to the problem, the writer focused on IRF (Initiation-ResponseFeedback) on Classroom Interaction For Computer In SMK 1 Yapim Medan. The discussion would be focused on the classroom interaction between teacher and students whether or not will influence the learning activities and learning outcomes. 


\section{REVIEW OF LITERATURE}

Discourse analysis is not only widely recognized as one of the vastest, but also the least defined areas in linguistics. One reason for this statement is that our understanding discourse analysis is based on scholar from a number of academic disciplines that are actually very different from one to another.

Classroom interaction plays important role in the teaching learning process. Dagarin (2004) defines classroom interaction can be defined as a two- way process between the participants in the learning process.

Goronga (2013) asserts that the clasroom interaction makes the students participating in the teaching and learning process. It means that classroom interaction encourages the students to involve. What's more, classroom interaction is not only about participation in the teaching and learning process and sharing their knowledge of a material at each other, but it was also about a relationship at each student to other students in the classroom.

In addition, there are some researches about classroom interaction. First, Maratmi (2013) studied about An Analysis On Classroom Interaction Using Irf (Initiation-Response-Follow Up) In Teaching And Learning Process At IxE Grade Smp N 2 Seririt. The objectives were to describe types of classroom interaction are used by English teacher and students during teaching and learning process in SMP N

2 Seririt, the functions of each type of classroom interaction during teaching and learning process in SMP N 2 Seririt. The result of the analysis showed that there were nine types of Sinclair and Coulthard (1975) theory occurred during the interaction in 
the class which is known as IRF (initiation-response-follow up). Respectively the types were as follows: question, inform, invitation, direction, prompt, encouragement, ignoring, acknowledge and response. The second, Rustandi (2017) concerned An Analysis of IRF (Initiation-Response-Feedback) On Classroom Interaction in EFL Speaking Class. This study aim at analyzing the reflection of IRF (InitiationResponse-Feedback) in speaking class and investigating the dominant sequence among I, R and F. IRF is a pattern of classroom interaction found by Sinclair and Coulthard in 1975 that stands for teacher initiation, students' response and feedback by the teacher. The result of this research was student's response becomes the dominant sequence of IRF in speaking class.

\section{RESEARCH METHODOLOGY, ANALYSIS, DISCUSSION AND FINDINGS Methodology}

This research was conducted by applying descriptive qualitative design. How the classroom interaction in teaching of English to Computer students is conducted would be described in narration and description of the reasons underlying the performance would be explained. Therefore the qualitative research design was called by objective explanation description.

The analysis consists of four current flows of activities It was the interactive model of Miles, Huberman and Saldana (2014), they are ; 1). Data Collection. Data that are in form of information are gotten by researcher from interview transcript (result of interviewed with some teachers and students), 2) Data Reduction. The 
researcher selected the data (the recording conversation in the classroom interaction) then transcribed it into written up field notes or transcriptions. The irrelevant data which were not related to research questions were discarded, 3) Data Display. This step is done by presenting a set of data because the data obtained during the classroom interaction process for computer students class is in the form of narrative, thus requiring simplification without reducing its contents, 4). Conclusion. After displaying the data, a then, sorted and organized the data (transcribed, interview and questionaire) to get the final conclusion.

\section{Analysis}

The first step done by the researcher was analysis. It was conducted by having observation for $2 \times 45$ minutes in teaching learning process for grammar passive voice and reading comprehension about internet, giving the questionnaire to students and interviewing the teacher. From the questionnaires, it was found that the students were difficult to speak English. The result of interview indicated that the teacher had problem in speaking English in the classroom.

\section{Findings}

The findings of this research were first, the teacher and students seldom used English in the classroom. The teacher responded various answered by using English and bahasa. the teacher used English and Bahasa to make students understand her lesson and because the students can't speak English well. The teacher always tried to speak English in the classroom interaction. Second, every interaction between teacher and students started by teacher question. In teaching learning process the teacher always 
gave questions to the students as initiation. After giving initiation, the students would respond the teacher questions.

\section{Discussion}

The teacher got problem when they had interaction in English with the students. It was happened because the students are not able to speak English. When the teacher speaks English, there was no interaction or respond from the students. The students looked difficult to respond the teacher by using English. The percentage of using English in the interaction between the teacher and students can be seen below.

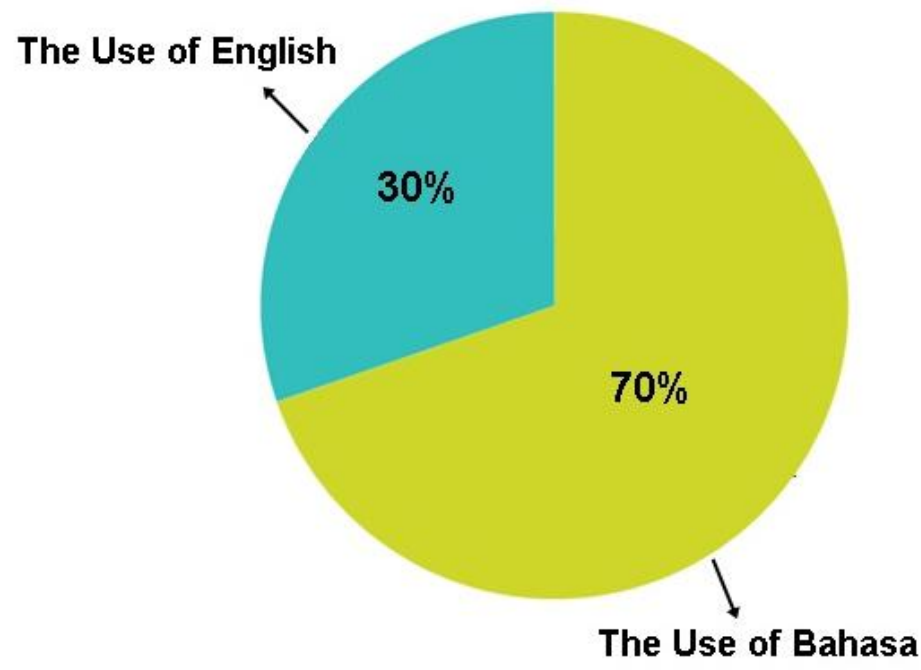

Figure 1: The Percentage of Using English in the Interaction Between the Teacher and Students

Both teacher and students used bahasa for $70 \%$ and the rest $30 \%$ they use English. Actually the teacher didn't face the difficulty in managing the class. Because the 
students paid attention in studying English. But it was hard for the students to understand English well.

Every interaction is always initiated by the teacher question and then followed by the students response by giving opinion toward the teacher question and finally the teacher gave feedback. The IRF pattern in the classroom interaction for studying passive voice and reading comprehension including the percentage of type can be seen in table 1 below.

Table 1 IRF Pattern

\begin{tabular}{|c|l|c|c|}
\hline \multirow{2}{*}{ NO } & \multicolumn{1}{|c|}{ TYPE } & \multicolumn{2}{c|}{ OBSERVATION } \\
\cline { 3 - 4 } & & Passive voice & $\begin{array}{c}\text { Reading } \\
\text { Comprehension }\end{array}$ \\
\hline 1. & $\begin{array}{l}\text { Teacher } \\
\text { Initiaton }\end{array}$ & $35 \%$ & $30 \%$ \\
\hline 2. & $\begin{array}{l}\text { Students } \\
\text { Response }\end{array}$ & $40 \%$ & $20 \%$ \\
\hline 3. & $\begin{array}{l}\text { Teacher } \\
\text { Feedback }\end{array}$ & $25 \%$ & $50 \%$ \\
\hline & \begin{tabular}{l} 
Total \\
\hline
\end{tabular}
\end{tabular}

From the table above, it can be concluded that in the first result was learning grammar passive voice, the teacher initiation was high but the students response was higher. The students looked happy and enthusiastic in learming it. Although they had problem in changing verb but they wanted to try to do the exercises given by the teacher. And the teacher feedback got in lowest position. So in learning passive voice the response of the students was dominat in pattern rather than initiation and feedback. 
Moreover, the second result of this study showed when students studied reading comprehension. The lowest pattern was student's response. It had $20 \%$ responses given to the students. It happened because the students made many mistakes in pronouncing some words when they read the text. The teacher feedback was the dominat pattern in the classroom interaction rather than initiation. This pattern happened because the problems that appeared from the features of the text, such there were unfamiliar vocabularies which were used in the text, unfamiliar content of the text which make the students were not interested to read, the appearance of an ambiguous pronoun which was confusing for the students.

\section{CONCLUSION AND SUGGESTION}

\section{Conclusions}

1. The language used by the teacher and the students in the classroom interaction was not balance. The students seldom use English. They used bahasa for $70 \%$ and 30\% used English. It is hard for the students to understand English well. it happened because the students had limited vocabulary and they also were afraid to make mistake when they spoke English.

2. The lowest pattern was student's response. It had $20 \%$ responses given to the students because the students made many mistakes in pronouncing some words when they read the text. The teacher feedback was the dominat pattern in the classroom interaction rather than initiation. This pattern happened because the students faced unfamiliar vocabularies which were used in the 
text, unfamiliar content of the text which make the students are not interested to read.

\section{Suggestion}

1. It is better if English teacher who is teaching computer students to stimulate students to use English in the teaching learning process. The classroom interaction between teacher and students can be interesting if there is two ways communication. But if the the teacher too dominant, of course the students will be passive in the class. And the teacher should improve the students English by having practice and supporting them to be brave to speak English.

2. The students should improve their English and dare to speak up English in the classroom. If they make mistake when they speak English, the teacher will be kindly to improve their mistakes.

3. The next researcher should to conduct further studies about classroom discourse based on Sinclair and Coulthard model which will be very useful reference to the teachers' and students' need in classroom interaction. 


\section{REFERENCES}

Brown, H. Douglas. 2001. Teaching by Principle: An Interactive Approach to Language Pedagogy. New York : Longman

Dagarin, Mateza. 2004. Classroom Interaction and Communication Strategies In Learning English as a Foreign Language. Sloven: Sloven University.

Dosma M.P.2017. An analysis Classroom Interaction in English Subject At Senior High School. Genre Jurnal. Volume 2 No.1 2017.

Friska O. 2017. Teacher Talk In English Classroom Interaction Using Sinclair And Coulthard Model. Journal of English Language Teaching of FBS Unimed, Vol 7, No.1, 2018.

Ginarsih, Sukirlan \& Supriyadi. 2013. An Analysis Of Classroom Interaction At The Second Year Of Smp 17 Gedongtataan. Unila Journal of English Teaching (UJET), Vol.2, No.4 2013

Miles,M.B, Huberman,A.M, dan Saldana,J. 2014. Qualitative Data Analysis, A Methods Sourcebook, Edition 3. USA: Sage Publications. Terjemahan Tjetjep Rohindi Rohidi, UI-Press

Nurul Wulanda.2017. Examining EFL Classroom Interaction Based on Sinclair and Coulthard Model.Register, Volume 1. No.2.2017.

Rohim, F. 2015. Materi Pelatihan Guru Implementasi Kurikulum 2013 Jenjang SMA/SMK Tahun 2015: Mata Pelajaran Bahasa Inggris. Kementrian Pendidikan dan Kebudayaan.

Rustandi, Andi (2013). Meaning negotiation between teachers and students in fledgling international standardized school. International journal of English and Education. Vol.2, Issue 3, July 2013.

Rustandi, Andi and Ande Husni Mubarok.2017. Analysis of IRF on classroom interaction in EFL Speaking Class. Edulite Jurnal, Volume 2 No.1, February 2017.

Sinclair, J. M., \& Coulthard, M. 1975. Toward an Analysis of Discourse: The English Used by Teachers and Pupils. London: Oxford University Press. 